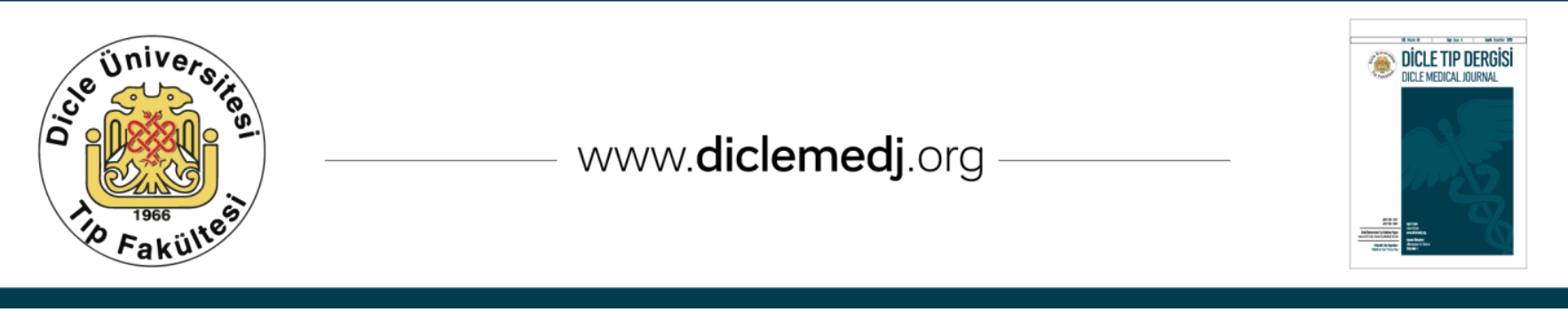

\title{
Prognostic importance of primary tumor location in RAS mutant metastatic colorectal cancer
}

\author{
Nadiye Akdeniz1, Muhammet Ali Kaplan², Mehmet Küçüköner ${ }^{3}$, Zuhat Urakçı ${ }^{4}$,

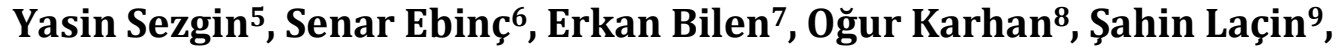 \\ Hüseyin Büyükbayram ${ }^{10}$, Abdurrahman Işıkdoğan ${ }^{11}$
}

1 Department of Medical Oncology, Dicle University Medical Faculty, Diyarbakır, Turkey ORCID: 0000-0002-4597-9721 2 Department of Medical Oncology, Dicle University Medical Faculty, Diyarbakır, Turkey ORCID: 0000-0003-0882-0524 3 Department of Medical Oncology, Dicle University Medical Faculty, Diyarbakır, Turkey ORCID: 0000-0001-7336-871X 4 Department of Medical Oncology, Dicle University Medical Faculty, Diyarbakır, Turkey ORCID: 0000-0003-3878-988X 5 Department of Medical Oncology, Dicle University Medical Faculty, Diyarbakır, Turkey ORCID: 0000-0003-4122-8389 6 Department of Medical Oncology, Dicle University Medical Faculty, Diyarbakır, Turkey ORCID: 0000-0002-0878-6525 7 Department of Medical Oncology, Dicle University Medical Faculty, Diyarbakır, Turkey ORCID: 0000-0002-7643-4054 8 Department of Medical Oncology, Dicle University Medical Faculty, Diyarbakır, Turkey ORCID: 0000-0002-7140-8957 9 Gazi Yasargil Education and Training Hospital, Medical Oncology, Diyarbakir ORCID: 0000-0002-8770-9842

10 Department of Pathology, Faculty of Medicine, Dicle University, Diyarbakır, Turkey ORCID: 0000-0002-7168-1507

11 Department of Medical Oncology, Dicle University Medical Faculty, Diyarbakır, Turkey ORCID: 0000-0002-7451-7286

Received: 11.01.2019; Revised: 20.02.2019; Accepted: 04.03.2019

\begin{abstract}
Objective: The prognostic value of tumor location in patients with metastatic colorectal cancer (mCRC) was reported by recent analyses in RAS wild-type patients. However, there is no enough specific data regarding prognostic value of primary tumor location in RAS mutated mCRC patients. We aimed to find if there is any relation between tumor prognosis and primary tumor location in patients with RAS mutated mCRC.

Method: This retrospective study included 57 patients with mCRC who were diagnosed and treated in our hospital between January 2011 and December 2017. Characteristics features of the patients were obtained from our institution patient medical records. Patients were included to the present study if KRAS or NRAS mutation was detected in tumor tissues.
\end{abstract}

DOI: 10.5798/dicletip.539998

Yazışma Adresi / Correspondence: Nadiye Akdeniz, Department of Medical Oncology, Dicle University Medical Faculty, Postal code: 21300 Diyarbakır, Turkey e-mail: nadiyeakdeniz21@gmail.com 
Results: Twenty-nine (50.9\%) of patients were female and the median age of all patients was 52 (18-80) years. Forty $(70.2 \%)$ of 57 patients were defined as left side (LS) and 17 (29.8\%) of patients were located in the right side (RS). As first line systemic treatment, twenty-five (43.9\%) patients had received oxaliplatin-based chemotherapy while 32 (56.1\%) patients had received irinotecan-based chemotherapy. Tumor sidedness did not affect on PFS (mPFS, 10.9 months for LS vs 8.1 months for RS, $\mathrm{p}=0.400$ ) and OS (mOS, 20.9 months for LS vs 20.8 months for RS, $\mathrm{p}=0.930$ ).The patients who had oxaliplatin based chemotherapy regimens showed better OS rate than irinotecan based regimens (28.7months vs16.3 months, $\mathrm{p}=0.017$, respectively).

Conclusion: Our study results support the thought that claims the sidedness of primary CRC in metastatic setting does not have effect on PFS and OS in patients with RAS mutant mCRC. However, our findings also underline the necessity of studies with larger patient populations and subgroup analyzes to evaluate potential prognostic and molecular features to determine the standart approach to this specific subgroup of the disease.

Keywords: Colorectal cancer, tumor location, RAS mutation, prognosis.

\section{RAS mutant metastatik kolorektal kanserde primer tümör yerleşiminin prognostik önemi}

\section{Öz}

Amaç: RAS wild metastatik kolorektak kanser (KRK) tanılı hastalarda tümör lokalizasyonun prognostik önemi hakkında çok sayıda çalışma bildirilmiştir. Ancak RAS mutant hastalar ile ilgili yeterli sayıda çalıșma bulunmamaktadır. Bu çalıșmada RAS mutant metastatik KRK tanılı hastalarda tümör yerleșim yerinin prognostik önemini belirlemeyi amaçladık.

Yöntemler: Bu retrospektif çalışmaya hastanemizde 2011 ve 2017 yılları arasında tanı alan RAS mutant metastatik KRK tanılı 57 hasta dahil edildi. Hasta özellikleri hastane kayıt sistemindeki verilerden elde edildi. KRAS veya NRAS mutasyonu saptanan hastalar dahil edildi.

Bulgular: Hastalardan 29 'u (\%50,9) kadın olup ortanca yaş 52 (18-80) idi. Primer tümör, hastaların 40'ında $(\% 70,2)$ sol kolon ve 17 'sinde $(\% 29,8)$ sağ kolonda yerleşim göstermekteydi. Yirmi beş $(\% 43,9)$ hasta oxaliplatin temelli ve 32 $(\% 56,1)$ hasta da irinotekan temelli kemoterapi almıștı. Primer tümör lokalizasyonuna göre progresyonsuz sağkalım (PSK) ve genel sağkalım (GSK) süreleri arasında istatiksel anlamlı fark saptanmadı (PSK sol kolonda 10.9 ay, sağ kolonda 8.1 ay, p=0.400 ve GSK sol kolonda 20.9 ay, sağ kolonda 20.8 ay, p=0.930). Oxaliplatin temelli tedavi alan hastaların irinotekan temelli tedavi alanlara göre GSK 'larının daha iyi olduğu görüldü (28.7 ay,16.3 ay, sırası ile $\mathrm{p}=0.017)$.

Sonuç: Çalışmamızda metastatik KRK hastalarında primer tümör yerleșim yerine göre guruplar arasında PSK ve GSK açısından fark saptanmadı. Ancak, bulgularımız bu hasta alt gurubu için standart yaklaşımın belirlenmesi için daha büyük hasta popülasyonları ve alt grup analizleri ile potansiyel prognostik ve moleküler özelliklerin değerlendirildiği çalışmalara olan ihtiyacın altını çizmektedir.

Anahtar kelimeler: Kolorektal kanser, tümör yerleşim yeri, RAS mutasyonu, prognoz.

\section{INTRODUCTION}

Colorectal cancer (CRC) is the third most common cancer in the world 1 . Due to the heterogeneous nature of CRC, many researches have been conducted on clinical, molecular prognostic and predictive factors which have dramatically increased knowledge in this field over the last decade and has improved patient management ${ }^{2-4}$. Nowadays, primary tumor location in CRC (right versus left-sided tumors) is accepted as one of the most important clinical prognostic factor has been described since 30 years ago ${ }^{5}$. 
The incidence rates of left- and right-sided CRC also differ markedly, with approximately twothirds of colorectal cancers (CRCs) originate from the left side (LS), and the remaining onethird of it originate from the right side (RS) ${ }^{6}$. Therefore, left- and right-sided CRCs are increasingly being accepted as separate tumour types which may be a reflection of their different embryological origin of the colon. Currently, right and left -sided tumours are also known as tumors that have different moleculer prognostic factors ${ }^{7}$.

The prognostic value of tumor location in patients with metastatic colorectal cancer (mCRC) was reported by recent analyses in RAS wild-type patients ${ }^{8-10}$. However, there is no enough specific data regarding prognostic value of primary tumor location in RAS mutated mCRC patients.In this study we aimed to find if there is any relation between tumor prognosis and primary tumor location in patients with RAS mutated mCRC.

\section{METHODS}

This retrospective study included the patients with mCRC who were diagnosed and treated in our hospital between January 2011 and December 2017. The study was approved by the Local Ethics Committee (permit: 12 /2018). Characteristics features of the patients such as gender, age, histologic subtype, tumor location, RAS mutation status, disease stage, history of surgery or radiation therapy, metastatic locations, and all treatment regimens were obtained from our institution patient medical records. Primary tumor location was defined as right or left sided if tumor located proximal or distal of the splenic flexure. This study included adult patients (aged $\geq 18$ years) with histologically confirmed metastatic KRAS or NRAS mutated colorectal adenocarcinoma. Patients with the following conditions were excluded from the study: malignancy other than CRC; KRAS and NRAS wild-type CRC; and non-metastatic colorectal cancer at the time of analysis.

The SPSS software version 18.0 was used for statistical analysis. Chi-square $(\chi 2)$ test was used to assess the association between clinicopathological characteristics and tumor sidedness. Mann-Whitney U test was used to compare median ages. Progression free survival (PFS) time was defined and calculated from the initial of the treatment time until disease first progression. The overall survival (OS) was defined as the duration time from the date of diagnosis to the date of the last control or death for any causes. The Kaplan-Meier curves were used to estimate survival and the log-rank test was used to compare and analyzethe survival data. Results were considered statistically significant at $p<0.05$ for all statistical tests.

\section{RESULTS}

A total of 57 patients with mCRC included in this study. Twenty-nine (50.9\%) of patients were female and the median age of all patients was 52 (18-80) years. In terms of histologic subtypes, $80.7 \%$ of patients were adenocarcinoma, $15.8 \%$ of patients were mucinous and remained $3.5 \%$ of patients were signet ring cell subtypes. Forty (70.2\%) of 57 patients were defined as LS and 17 (29.8\%) of the patients were located in the RS. Specifically just NRAS mutation was detected in 20 (35.1\%) patients. As first line systemic treatment, twenty-five (43.9\%) patients had received oxaliplatin-based chemotherapy while 32 (56.1\%) patients had received irinotecan-based chemotherapy. Bevacizumab had been given to $42(73.7 \%)$ patients. Liver was the most common site of metastasis and detected in 41 (71.9\%) of patients. Tumor histological subtype, NRAS mutation and lung metastasis showed significant association with tumor sidedness $(p=0.011, p=0.042, p=0.052$, respectively). All demographic and molecular 
characteristics according to sidedness were summarized in Table 1.

Table 1: Baseline patient characteristics.

\begin{tabular}{|c|c|c|c|c|}
\hline Characteristic & \begin{tabular}{|c|} 
Total=57 \\
N (\%) \\
\end{tabular} & \begin{tabular}{|c|}
$\begin{array}{c}\text { Left-side }=40 \\
\mathrm{~N}(\%)\end{array}$ \\
\end{tabular} & \begin{tabular}{|c|}
$\begin{array}{c}\text { Right-side }=17 \\
\mathrm{~N}(\%)\end{array}$ \\
\end{tabular} & $p$ value \\
\hline $\begin{array}{l}\text { Gender } \\
\text { Female } \\
\text { Male }\end{array}$ & $\begin{array}{l}29(50.9) \\
28(49.1)\end{array}$ & $\begin{array}{l}21(52.5) \\
19(47.5)\end{array}$ & $\begin{array}{l}8(47.1) \\
9(52.9)\end{array}$ & 0.707 \\
\hline $\begin{array}{l}\text { Age, } \\
\text { median (min-max) }\end{array}$ & $52(18-80)$ & $52.5(18-80)$ & $48(34-75)$ & 0.536 \\
\hline $\begin{array}{l}\text { Histologic subtype } \\
\text { Adenocarcinoma } \\
\text { Mucinous } \\
\text { Signet ring cell }\end{array}$ & $\begin{array}{c}46(80.7) \\
9(15.8) \\
2(3.5)\end{array}$ & $\begin{array}{c}36(90) \\
4(10) \\
-\end{array}$ & $\begin{array}{c}10(58.8) \\
5(29.4) \\
2(11.8)\end{array}$ & 0.011 \\
\hline $\begin{array}{l}\text { KRAS mutation } \\
\text { Yes } \\
\text { No }\end{array}$ & $\begin{array}{c}52(91.2) \\
5(8.8)\end{array}$ & $\begin{array}{l}36(90) \\
4(10)\end{array}$ & $\begin{array}{c}16(94.1) \\
1(5.9)\end{array}$ & 0.615 \\
\hline \begin{tabular}{|l|} 
NRAS mutation \\
Yes \\
No \\
Unknown \\
\end{tabular} & $\begin{array}{c}7(12.3) \\
13(22.8) \\
37(64.9)\end{array}$ & $\begin{array}{c}5(12.5) \\
13(32.5) \\
22(55)\end{array}$ & $\begin{array}{c}2(11.8) \\
- \\
15(88.2)\end{array}$ & 0.042 \\
\hline \begin{tabular}{|l|} 
Surgery \\
Yes \\
No
\end{tabular} & $\begin{array}{l}42(73.7) \\
15(26.3)\end{array}$ & $\begin{array}{l}27(67.5) \\
13(32.5)\end{array}$ & $\begin{array}{c}15(88.2) \\
2(11.8)\end{array}$ & 0.265 \\
\hline \begin{tabular}{|l|} 
Radiation \\
Yes \\
No \\
\end{tabular} & $\begin{array}{l}11(19.3) \\
46(80.7)\end{array}$ & $\begin{array}{l}11(27.5) \\
29(72.5) \\
\end{array}$ & $17(100)$ & 0.055 \\
\hline \begin{tabular}{|l|} 
Stage at diagnosis \\
II \\
III \\
IV \\
\end{tabular} & $\begin{array}{c}3(5.3) \\
17(29.8) \\
37(64.9)\end{array}$ & $\begin{array}{c}1(2.5) \\
12(30) \\
27(67.5)\end{array}$ & $\begin{array}{c}2(11.8) \\
5(29.4) \\
10(58.8)\end{array}$ & 0.353 \\
\hline \begin{tabular}{|l|} 
Adjuvant \\
chemotherapy \\
Yes \\
No \\
\end{tabular} & $\begin{array}{l}17(29.8) \\
40(70.2) \\
\end{array}$ & $\begin{array}{l}11(27.5) \\
29(72.5) \\
\end{array}$ & $\begin{array}{c}6(35.3) \\
11(64.7) \\
\end{array}$ & 0.556 \\
\hline \begin{tabular}{|l|} 
Chemotherapy \\
regimens for 1.line \\
Oxaliplatin based \\
İrinotecan based \\
\end{tabular} & $\begin{array}{l}25(43.9) \\
32(56.1) \\
\end{array}$ & $\begin{array}{l}19(47.5) \\
21(52.5) \\
\end{array}$ & $\begin{array}{c}6(35.3) \\
11(64.7) \\
\end{array}$ & 0.450 \\
\hline \begin{tabular}{|l|} 
Bevacizumab \\
Yes \\
No \\
\end{tabular} & $\begin{array}{l}42(73.7) \\
15(26.3) \\
\end{array}$ & $\begin{array}{l}30(75) \\
10(25)\end{array}$ & $\begin{array}{c}12(70.6) \\
5(29.4)\end{array}$ & 0.729 \\
\hline $\begin{array}{l}\text { Sites of metastasis } \\
\text { Liver } \\
\text { Lung } \\
\text { Peritoneum }\end{array}$ & $\begin{array}{l}41(71.9) \\
17(29.8) \\
11(19.3)\end{array}$ & $\begin{array}{c}30(75) \\
15(37.5) \\
6(15)\end{array}$ & $\begin{array}{c}11(64.7) \\
2(11.8) \\
5(29.4)\end{array}$ & $\begin{array}{l}0.429 \\
0.052 \\
0.207\end{array}$ \\
\hline
\end{tabular}

The median PFS and OS rate of the whole population was 9.8months (6.7-12.9) and 20.9 months (13.7-28.3), respectively. Tumor sidedness did not affect PFS (mPFS, 10.9 months for LS vs 8.1 months for RS, $\mathrm{p}=0.400$ ) and OS (mOS, 20.9 months for LS vs 20.8 months for RS, $p=0.930$ ) (Figure 1). Liver metastatic patients were found had worse PFS and $O S$ rates than the patients without liver metastatic disease (mPFS, 8.1months and mOS, 18.6 months, $\mathrm{p}=0.033, \mathrm{p}=0.024$, respectively) (Figure 2). In our analysis, the patients who had oxaliplatin based chemotherapy regimens showed better OS rate than irinotecan based regimens (28.7months vs16.3 months, $\mathrm{p}=0.017$, respectively) (Figure 3). The PFS and OS rates according to tumor characteristics and treatment regimens were shown in Table 2.

Table 2: Progression-free survival and Overall survival according to tumor characteristics and treatment regimens.

\begin{tabular}{|c|c|c|c|c|}
\hline & \begin{tabular}{|c|} 
PFS \\
Median(min- \\
max) \\
month \\
\end{tabular} & $\begin{array}{c}p \\
\text { value }\end{array}$ & $\begin{array}{c}\text { OS } \\
\text { Median (min- } \\
\text { max) } \\
\text { month }\end{array}$ & $\begin{array}{c}P \\
\text { value }\end{array}$ \\
\hline All of patients & $9.8(6.7-12.9)$ & & $20.9(13.7-28.3)$ & \\
\hline $\begin{array}{l}\text { Left-side } \\
\text { Right -side }\end{array}$ & $\begin{array}{l}10.9(7-14.7) \\
8.1(3.2-13.1)\end{array}$ & 0.400 & $\begin{array}{c}20.9(13.7-28.3) \\
20.8(9.4-32.3)\end{array}$ & 0.930 \\
\hline $\begin{array}{l}\text { Liver metastasis } \\
\text { Yes } \\
\text { No }\end{array}$ & $\begin{array}{c}8.1(6.1-10.2) \\
14.1(7.5-20.5)\end{array}$ & 0.033 & $\begin{array}{c}18.6(14.1-23) \\
33.2(19.2-47.2)\end{array}$ & 0.024 \\
\hline $\begin{array}{l}\text { Lung metastasis } \\
\text { Yes } \\
\text { No }\end{array}$ & $\begin{array}{c}10.9(7.8-13.9) \\
8.2(5.5-10.9) \\
\end{array}$ & 0.834 & $\begin{array}{c}25(15.5-34.6) \\
19.9(12.9-26.7) \\
\end{array}$ & 0.671 \\
\hline \begin{tabular}{|l|} 
Peritoneum \\
metastasis \\
Yes \\
No \\
\end{tabular} & \begin{tabular}{|}
$10.9(8.2-13.6)$ \\
$8.7(6.4-11)$
\end{tabular} & 0.468 & $\begin{array}{c}33.2(10.4-55.9) \\
20.8(17-24.5)\end{array}$ & 0.265 \\
\hline \begin{tabular}{|l|} 
Oxaliplatin based \\
İrinotecan based \\
\end{tabular} & \begin{tabular}{|c|}
$11.1(8.4-13.8)$ \\
$8.1(5-11.3)$ \\
\end{tabular} & 0.415 & $\begin{array}{c}28.7(20.5-36.8) \\
16.3(7.2-25.3) \\
\end{array}$ & 0.017 \\
\hline \begin{tabular}{|l|} 
KRAS mutation \\
Yes \\
No \\
\end{tabular} & \begin{tabular}{|c|}
$9.7(7.3-12)$ \\
$11.7(5.7-17.7)$ \\
\end{tabular} & 0.535 & $\begin{array}{c}20.8(15.2-26.5) \\
26.3(2.5-50)\end{array}$ & 0.544 \\
\hline \begin{tabular}{|l|} 
NRAS mutation \\
Yes \\
No \\
\end{tabular} & \begin{tabular}{|c|}
$11.7(6.7-16.6)$ \\
$7.9(5.9-9.9)$ \\
\end{tabular} & 0.504 & $\begin{array}{l}26.3(9.2-43.3) \\
21.7(9.1-34.3)\end{array}$ & 0.461 \\
\hline
\end{tabular}



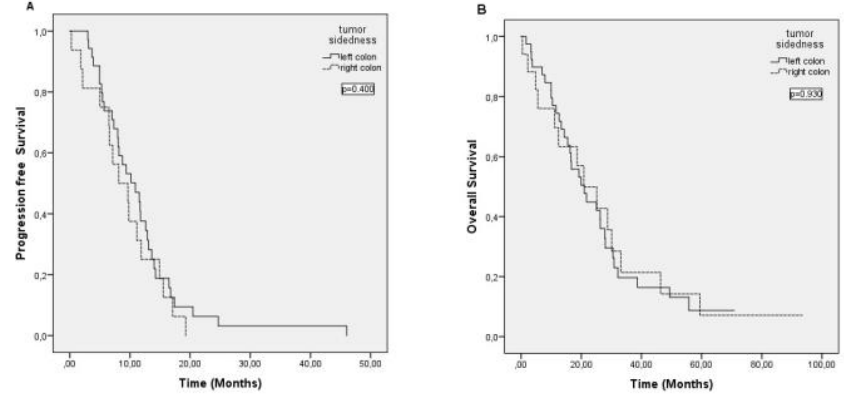

Figure 1A-B. Median progression-free survival (A) and median overall survival (B) results according to primary tumor location.
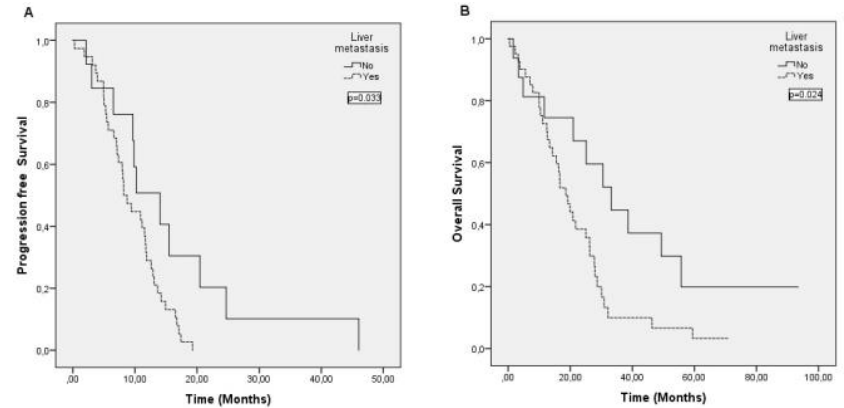

Figure 2A-B. Median progression-free survival (A) and median overall survival (B) results according to liver metastasis.

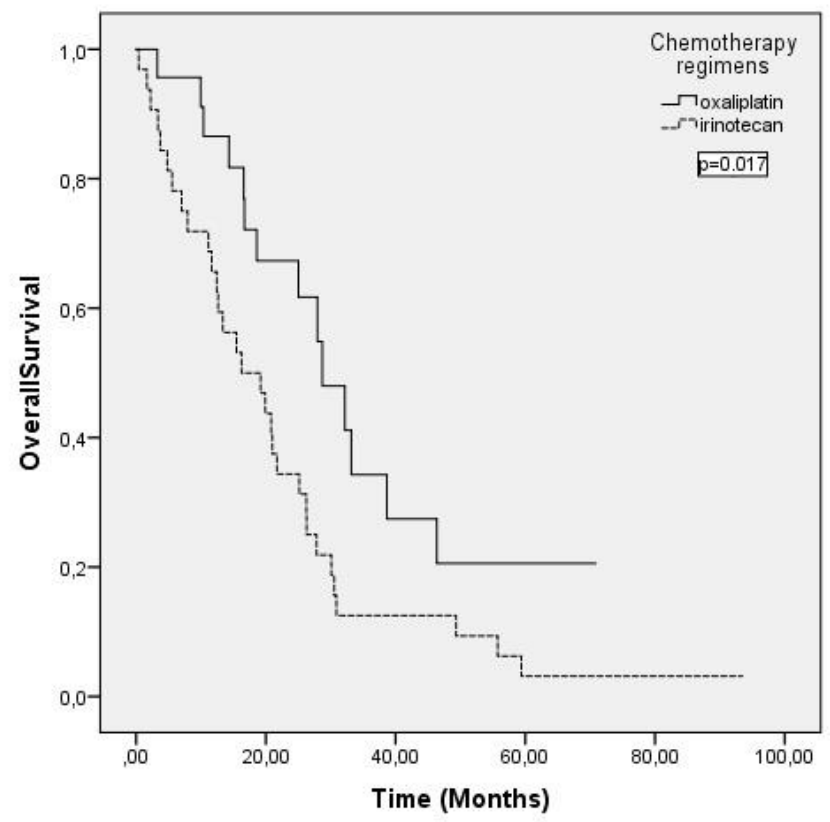

Figure 3. Median progression-free survival (A) and median overall survival (B) results according to chemotherapy regimens.

\section{DISCUSSION}

In the recent years, many emerged data has showed that identification of right and leftsided CRCs is crucial and defined them as two distinct clinical, pathological and molecular diseases ${ }^{11}$. According to the most recent guidelines, primary tumor location of CRC is a fundamental feature in the definition of patients prognosis and therapeutic approaches. On these bases, we analyzed the prognostic importance of tumor location in a population of patients with RAS mutated MCRC. Because it is also important to note that the most wellknown studies on this subject (CALGB/SWOG 80405, FIRE-3, CRYSTAL, PEAK, and PRIME) included only patients with wild-type K-RAS tumors and the main objective of these trials was to compare the survival rates after antiEGFR administration in standard regimens without either monoclonal antibody or antiVEGF $^{8-10}$. Since there are few data regarding the patients with RAS mutant metastatic colorectal cancer that has been reported in the literature, our study shed some lights on this area. In this context, Loupakis et al.also evaluated the prognostic value of tumor location in patients with RAS mutated mCRC. Their study showed no difference in median OS according to primary tumor location (mOS, 31.2 months for LS vs. 32.9 months for RS, $p=0$.972), and also there was no any differences that observed in specific RAS mutations subtypes ${ }^{12}$. Our study results were consistent with these findings that showed no difference in median OS according to primary tumor location. In terms of PFS, there was no statistical difference between mPFS and primary tumor location and additionally no differences were observed with specific KRAS and NRAS mutation subtypes and primary tumor location for both PFS and OS. Despite in reported two previous study that didn't show association between specific NRAS mutation subtype and tumor sidedness $(\mathrm{p}=0.238, \mathrm{p}=0.358 \text {, respectively })^{12,13}$, we found a relationship between NRAS mutation and 
tumor sidedness $(\mathrm{p}=0.042)$. However, this result may be related to the less number of patients with NRAS mutation subtype in our study and should be supported by studies with larger patients population.

Chemotherapy is the main treatment of CRC and the selection between FOLFOX and FOLFIRI as standard first line backbone treatment is optional which depend on many factors. Significant difference between two main treatment protocol in terms of response rate, $\mathrm{PFS}$, and $\mathrm{OS}$ has not been reported in the literature that based on reported trials. The results that reported from the one of these trials are being obtained from phase III trial which comparing the efficacy FOLFOX and FOLFIRI regimens in previously untreated patients with mCRC. No differences were observed in response rate, PFS times, and OS between the treatment arms regardless of the RAS mutation ${ }^{14}$. In another study, the patients with KRAS mutant metastatic colorectal tumors had been evaluated and the study reported that median OS was 23.4 months with oxaliplatinbased chemotherapy regimen and 23.6 months with irinotecan-based chemotherapy regimen, with no significant difference $(\mathrm{p}=0.27)^{15}$. In contrast to these trials, the comparison of two chemotherapy regimens in our study reported that oxaliplatin based chemotherapy regimen had better os rate than irinotecan based chemotherapy regimen which was statistically significant (28.7 vs16.3 months, $\mathrm{p}=0.017$,respectively). These results were not consistent with the literature, heterogeneous patient population and low number of patients are the possible reasons that we thought.

The major limitations of the study were small number of patients and lack of BRAF mutation status. However, because of limited reported studies and data regarding importance of primary tumor sidedness in patients with RAS mutant $\mathrm{mCRC}$, our exciting results may help to attract attention to this field.
In conclusion, our results support the thought that the sidedness of primary colon cancer does not affect PFS and OS in patients with RAS mutant mCRC. However, our findings also underline the necessity of studies with larger patient populations and subgroup analyzes in the evaluation of potential prognostic clinical and molecular features in order to avoid misleading conclusions. Therefore, for the standard approachment we need to concrete evidences that obtained from large-scale trials that included the patients with this specific subgroup of metastatic colorectal cancer.

Conflicts of interest: The authors have no conflict of interests to declare.

Financial Disclosure: The authors declared that this study has received no financial support.

\section{REFERENCES}

1. Ferlay J, Soerjomataram I, Dikshit R, et all. Cancer incidence and mortality worldwide: sources, methods and major patterns in GLOBOCAN 2012. Int J Cancer. 2015; 136: 359-86.

2. Guinney J, Dienstmann R, Wang X,et all. The consensus molecular subtypes of colorectal cancer. Nat Med. 2015; 21: 1350-6.

3. Auclin E, Zaanan A, Vernerey D,et all. Subgroups and prognostication in stage III colon cancer: future perspectives for adjuvant therapy. Ann Oncol Off JEur Soc Med Oncol. 2017; 28: 958-68.

4. Lie`vre A, Bachet J-B, Boige V, et all. KRAS mutations as an independent prognostic factor in patients with advanced colorectal cancer treated with cetuximab. J Clin Oncol Off J Am Soc Clin Oncol. 2008; 26: 374-9.

5. Rothberg PG, Spandorfer JM, Erisman MD, et all. Evidence that c-myc expression defines two genetically distinct forms of colorectal adenocarcinoma. $\mathrm{Br} \mathrm{J}$ Cancer. 1985; 52: 629-32.

6. Meza R, Jeon J, Renehan AG, Luebeck EG. Colorectal cancer incidence trends in the United States and United Kingdom: evidence of right- to left-sided biological gradients with implications for screening. Cancer Res 2010; 70: 5419-29.

7. Van Cutsem E, Cervantes A, Adam R et all. ESMO consensus guidelines for the management of patients with metastatic colorectal cancer. Ann Oncol 2016; 27: 1386-1422. 
8. Venook AP, Niedzwiecki D, Innocenti F, et al. Impact of primary $\left(1^{\circ}\right)$ tumor location on overall survival (OS) and progression-free survival (PFS) in patients (pts) with metastatic colorectal cancer (mCRC): analysis of CALGB/SWOG 80405 (Alliance). J Clin Oncol. 2016; 34: 3504.

9. Tejpar S, Stinzing S, Ciardello F, et all. Prognostic and predictive relevance of primary tumor location in patients with RAS wild-type metastatic colorectal cancer: retrospective analyses of the CRYSTAL and FIRE-3 trials. JAMA Oncol. 2016

10. Boeckx N, Koukakis R, Op de Beeck K, et all. Primary tumor sidedness has an impact on prognosis and treatment outcome in metastatic colorectal cancer: results from two randomized first-line panitumumab studies. Ann Oncol. 2017; 28: 1862-68.

11. Missiaglia E, Jacobs B, D'Ario G et all. Distal and proximal colon cancers differ in terms of molecular, pathological, and clinical features. Ann Oncol 2014; 25: 1995-2001.
12. Loupakis F, Schirripa M, Intini R, et all. Another Chapter of the Right Versus Left Story: Is Primary Tumor Location a Prognostic Feature in RAS Mutant Metastatic Colorectal Cancer?.Oncologist. 2018; 3: 1-3.

13. Rimbert J, Tachon G, Junca A, et all. Association between clinicopathological characteristics and RAS mutation in colorectal cancer.Mod Pathol. 2018 Mar; 31: 517-26.

14. Colucci G, Gebbia V, Paoletti G, et all. Phase III randomized trial of FOLFIRI versus FOLFOX4 in the treatment of advanced colorectal cancer: a multicenter study of the Gruppo Oncologico Dell'Italia Meridionale. J Clin Oncol 2005; 23: 4866-75.

15. Cabart M, Frénel JS, Campion L, et all. KRAS mutation does not influence oxaliplatin or irinotecan efficacy, in association with bevacizumab, in first line treatment of metastatic colorectal cancer.Bull Cancer. 2016 Jun; 103: 541-51. 